\title{
Carnets
}

Revue électronique d'études françaises de l'APEF

Première Série - 2| 2010

L'équivoque

\section{Équivoques parisiennes}

\section{Pedro Guerra}

\section{(2) OpenEdition}

Journals

Édition électronique

URL : http://journals.openedition.org/carnets/4736

DOI : $10.4000 /$ carnets.4736

ISSN : 1646-7698

Éditeur

APEF

Édition imprimée

Date de publication : 1 janvier 2010

Pagination : 150-151

\section{Référence électronique}

Pedro Guerra, "Équivoques parisiennes », Carnets [En ligne], Première Série - 2 | 2010, mis en ligne le 16 juin 2018, consulté le 24 septembre 2020. URL : http://journals.openedition.org/carnets/4736 ; DOI : https://doi.org/10.4000/carnets. 4736

Ce document a été généré automatiquement le 24 septembre 2020.

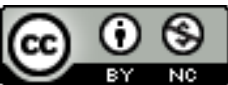

Carnets est mis à disposition selon les termes de la licence Creative Commons - Atribution - Pas d'utilisation commerciale 4.0 International. 


\section{Équivoques parisiennes}

\section{Pedro Guerra}

Pedro Guerra - Équivoques parisiennes

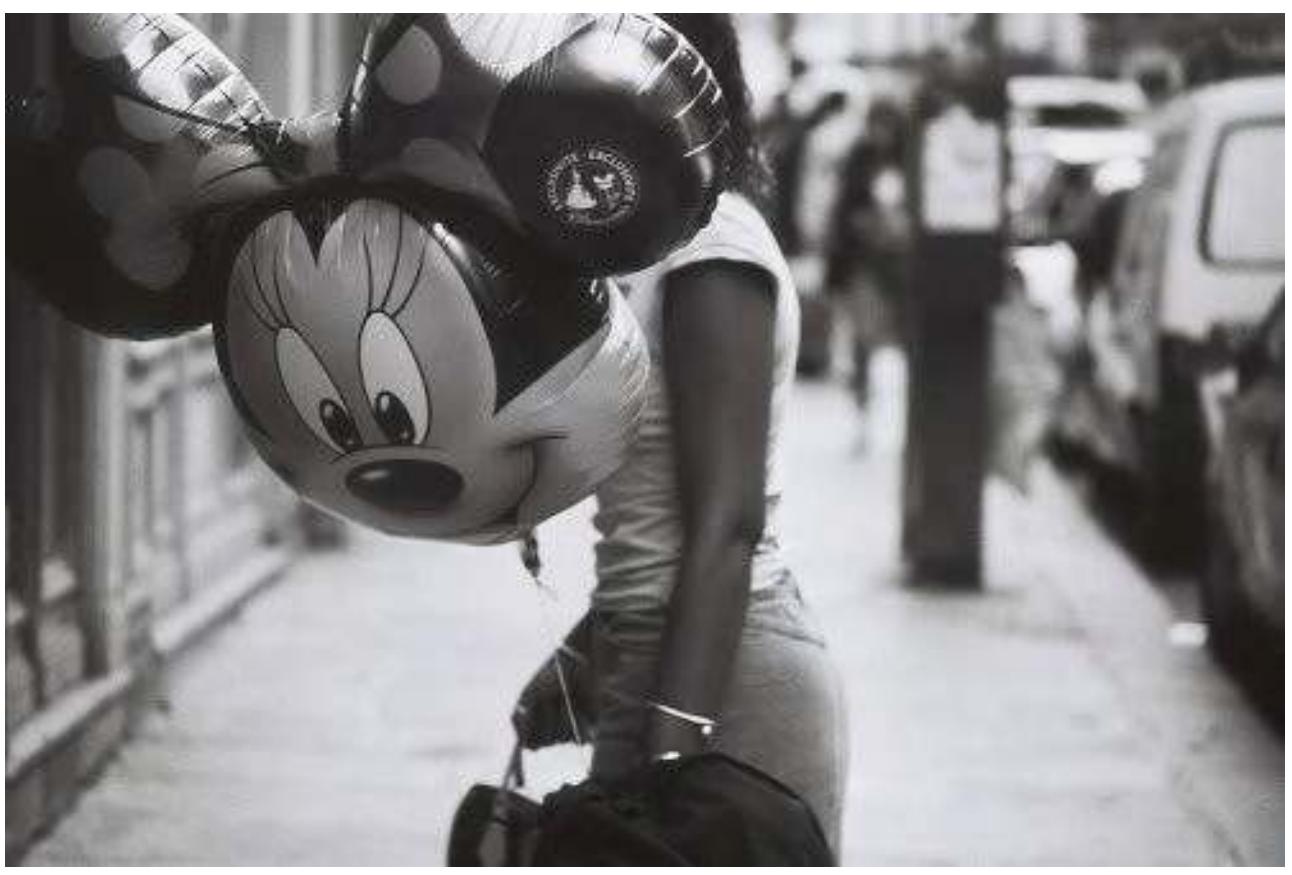


Pedro Guerra - Équivoques parisiennes

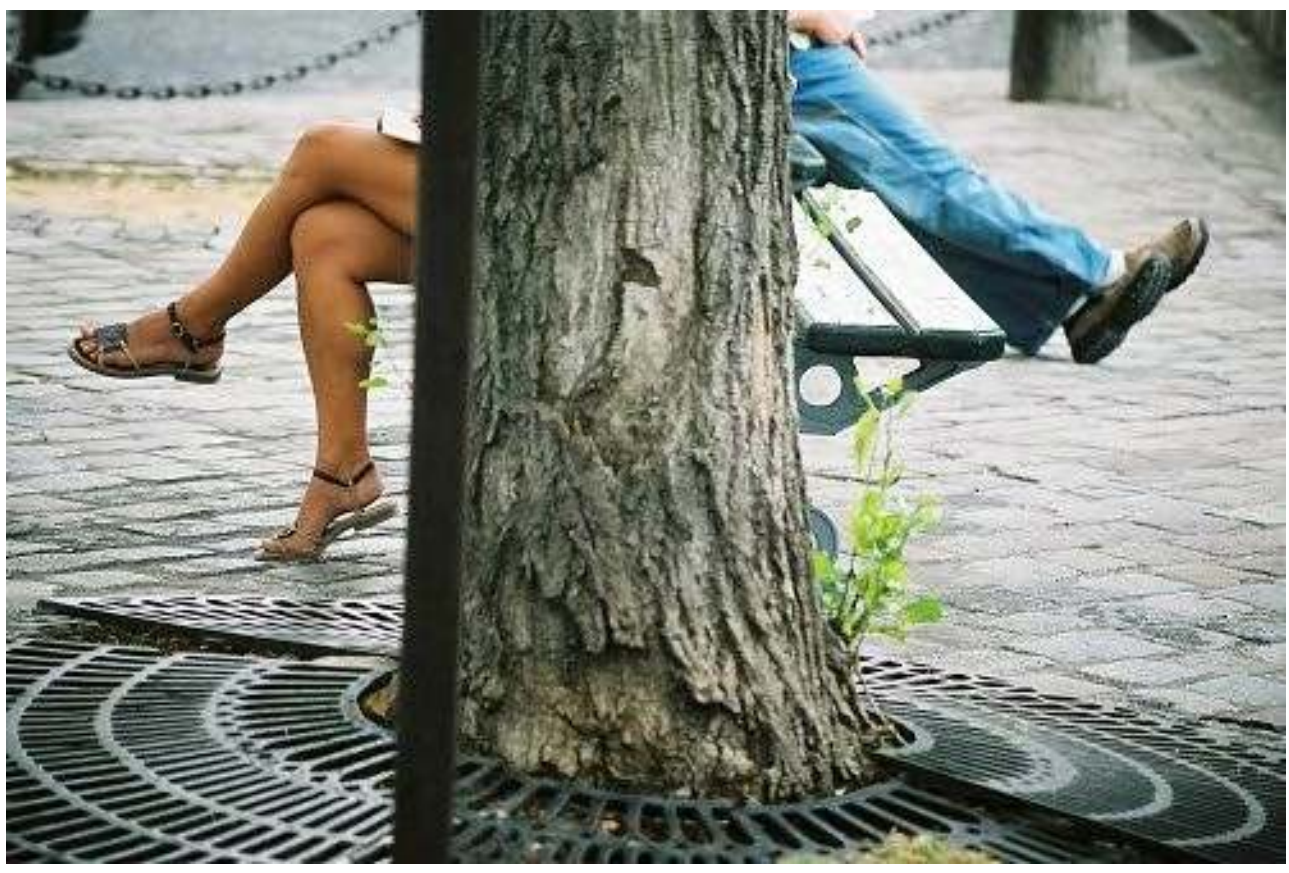

